Article

\title{
Toward an Evolutionary and Sustainability Perspective of the Innovation Ecosystem: Revisiting the Panarchy Model
}

\author{
James Boyer ${ }^{(1)}$ \\ Lille Economy and Management, HÉMiSF4iRE Design School, Catholic University of Lille, 59800 Lille, France; \\ James.Boyer@univ-catholille.fr
}

Received: 25 March 2020; Accepted: 14 April 2020; Published: 16 April 2020

\begin{abstract}
This paper proposes an evolutionary and sustainability perspective of the innovation ecosystem. This study revisits the Panarchy model in order to generate new perspectives on the innovation ecosystem. The Panarchy model describes the evolutionary nature of complex adaptive systems relying on four phases, without, however, being deterministic: exploitation, conservation, decline, and reorganization. When ecosystems face important shocks, adaptive mechanisms and properties within the ecosystem lead the ecosystem to a new reorganization phase, which gives birth to another exploitation phase. In this perspective, the innovation ecosystem allows the avoidance of technology lock-ins and structural and organizational rigidity by providing mechanisms to enhance both resilience and competitiveness. Innovation ecosystem sustainability relies on two major dual forces: the exploitative function and the generative or autopoiesis function. Therefore, evolutionary and sustainability perspectives remain the "natural home" for developing works and models about the innovation ecosystem, and instrumental for policy-makers and practitioners involved in innovation management.
\end{abstract}

Keywords: innovation ecosystem; sustainability; evolutionary economics; Panarchy; resilience; adaptation; competitiveness

\section{Introduction}

During the past two decades, a great deal of interest in ecosystem research in management and economic fields has developed [1-3]. A growing number of scientific studies have popularized the concept of the innovation ecosystem as a new framework for academia, policy-makers, and practitioners [4-6]. Thus, more and more policymakers and economic agents are resorting to the innovation ecosystem framework, which highlights the role of open innovation, and actors' collaboration and co-evolution, as well as knowledge production and transfer.

An innovation ecosystem can be defined as a dynamic and adaptive system characterized by complex (formal, informal, organic, or institutional) relationships between a set of heterogeneous actors, performing distinct activities, playing different roles and having various motivations and capabilities, which contribute to the development of innovation processes or technologies [7-9]. From an evolutionary and ecological perspective, this notion remains strongly committed to the original biological metaphor. Moore introduced the concept of the "business ecosystem" to develop the thesis of firms' coevolution in a strategic context, in opposition to blind competition [1]. Frosch and Gallopoulos, on the other hand, developed the "industrial ecosystem" concept to advance the idea that a strategic context with interdependencies between heterogeneous actors could make it possible to develop innovative logics of circularity and environmentally friendly recycled products within the manufactoring sector [10]. 
The approach that developing innovation processes and competitive advantage relies on a business-friendly environment with complex relationships between actors is not new. The Marshallian hypothesis on "industrial districts" have already described the importance of geographic and relational proximity characterized by complementarities and interdependences between a diversity of economic actors regarding the competitiveness of a given territory [11]. Becattini, in the 1980s, expanded the concept of Industrial districts to characterize Italian districts' competitiveness [12]. Porter delved deeper into this concept and popularized, in the 1990s, the cluster concept, which is defined as a concentration of small, medium, or large firms, organizations, and institutions, which are in synergy in a particular technological field within a geographic area [13]. At the same time, evolutionary economists have developed the concept of the "innovation system" as incorporating the role of institutions in the structuring (at different scales: sector, territorial, or topological) of this strategic and interactionist environment favoring the development of innovation processes [14-17].

Given such an abundant theoretical corpus, many are critical of and skeptical about the potential contribution of the innovation ecosystem concept. According to Oh et al., the added value this concept generates is so low that its mobilization exposes the researcher much more to questionable scientific rigor and invalid knowledge production. Its use can even lead to harmful and dangerous political and strategic choices [18]. Faced with these criticisms, the ecosystem concept has become a more and more contested concept, calling for more robust conceptual and theoretical foundations. In addition, these criticisms highlight the need for concrete operationalization of this concept for policy-makers and practitioners.

This article proposes an evolutionary and sustainability perspective of the innovation ecosystem in order to offer an answer to the call for conceptual rigor to this concept. Moreover, this paper addresses the main implications for performance measures and the sustainability conditions of innovation ecosystems.

This study uses an evolutionary and sustainability perspective of innovation ecosystems. We revisit the adaptive cycle, known as "Panarchy", developed by Gunderson and Holling [19]. The Panarchy model was developed to describe the evolutionary nature of complex adaptive systems and their sustainability. It has been applied mainly to natural ecosystems (forests, meadows, lakes, rivers, and seas), socio-economic systems (territorial governance structures), as well as socio-ecological systems.

Because the ecosystem of innovation concept was originally an ecological metaphor, and since many scholars use it as a complex adaptive system [20]), it seems relevant to know to what extent the Panarchy model can be applied to the innovation ecosystem concept and how this can reveal specific features of this concept.

The first part of this paper highlights the theoretical foundations and main approaches to innovation ecosystems, as several bibliometric works have referenced them. The second part explains our methodological framework. The third part tests the adaptive cycle main hypotheses on two emblematic cases of innovation ecosystems. Finally, we discuss propositions arising from this analysis to bring out the properties of innovation ecosystems and their implications in terms of performance, sustainability, collective strategies, and public policies.

\section{Innovation Ecosystems, Theoretical Foundations, and Main Approaches}

A cross-analysis of two bibliometric works carried out on the innovation ecosystem concept in economic and management fields allows us to identify five main theoretical corpora, with a major influence on the development of the innovation ecosystem framework $[5,6]$.

The first corpus is the Open Innovation framework [21,22]. From this viewpoint, the innovation ecosystem is a system of complex relationships between various actors in the context of open innovation [23,24].

The second corpus is the Strategic Management field [25-27]. With that in mind, the ecosystem is seen as a strategic context on which companies' performances depend. It provides a framework that fosters the emergence and development of innovations and technologies in order to improve value creation and competitiveness [28,29]. 
The third corpus is the Organization Studies field [30,31]. The innovation ecosystem is, therefore, a collaborative organizational and institutional arrangement in which companies and other economic players combine their knowledge, know-how, and methods consistently to foster the development of innovation processes [8,32].

The fourth corpus is that of Evolutionary Economics [33]. From this perspective, the innovation ecosystem is considered as a complex adaptive system, characterized by permanent interactions between various actors, which allows the combination of top-down and bottom-up initiatives that contribute to developing innovations. Actors' coevolution and ecosystem dynamics are then critical.

The fifth corpus is the Industrial Ecology field (this has currently been identified by the bibliometric work of Tsujimoto et al.) [5,10,34]. From this viewpoint, the concept used is the "industrial ecosystem", which is a much deeper analogy of the natural ecosystem. The main hypothesis relies on the transformation of the industrial system through limiting the industrial impacts on environmental and natural resources by optimizing the production of goods and materials besides energy flows.

The three main approaches structure the work on innovation ecosystems: the platform based-ecosystem or digital ecosystem, the regional/local ecosystem, and the industrial ecosystem. In the literature, the difference between the innovation ecosystem and the business ecosystem is not clear. Augusto et al., explain the difference: the innovation ecosystem focuses on value creation, whereas the business ecosystem is about capturing value [6]. Our study uses a cross-cutting approach that integrates both value creation and value capture.

The platform-based ecosystem approach highlights mainly the role of digital platforms [35-37]. The ecosystem is, therefore, an open and collaborative space built from various actors' interactions around a pivotal company or a keystone [38-40]. This ecosystem is structured around a multi-sided platform with at least two main faces. The first one enables the leader, stakeholders, and peripheral players or developers communities to design and develop complementary innovative products and services. The second one facilitates the management, sale, or monetization of new products and services between platform stakeholders and users or customers. Both sides favor exploiting data on the evolution of customers' behaviors, practices, and preferences. They ease up the continuous improvement of the digital platform's products and services. Digital platforms, therefore, foster complex and dynamic interactions, complementarities, and automated transactions between a variety of players (customers, developers, users, and suppliers).

The Regional/Local Ecosystem approach is an extension of Saxenian's work, highlighting the territorial or regional dimension in the dynamics of the innovation process [41]. These works point out the central role of geographic proximity and interactions between actors and institutions in the development of innovation processes $[42,43]$. Works on creative cities or creative ecosystems have made one of the most relevant contributions. They place the same level of emphasis on formal and informal relationships, institutions' dynamics, and epistemic communities. These entities foster as well as exploration and creativity or exploitation and development of new products or services [44-47]. According to these works, the innovation ecosystem has three main components, which are in organic interaction:

(i) The upperground. It is made up of stable, formal entities with a great capacity for exploitation, development, and standardization (e.g., companies, universities, innovation agencies, public institutions);

(ii) The underground: It is made up of talented, marginal or alternative elements, artists, informal collectives, which essentially play a major role in the exploration and generation of new ideas;

(iii) The middleground, i.e., spaces, places, actors, and communities that connect the actors of the underground and those of the upperground.

The performance of the innovation ecosystem therefore depends on the quality of the middleground or the quality of the organic relationships between formal and informal entities.

The third approach is the industrial ecosystem connected to the industrial ecology field, as we explained above [10]. The industrial ecosystem approach is the one that best embodies the ecological 
dimension and legitimizes the prefix "eco". This approach is linked to a broader perspective of sustainable development. This approach opposes a linear vision of material and energy flows. It relies on the assumption of a "perfect industrial system", which minimizes its impact on the environment and natural resources through cyclic or circular processes [48]. Within complex collaboration, heterogeneous actors develop then innovation processes to

(i) promote circular economy renewable energies, recycling products;

(ii) reduce drastically industrial, natural resources, and energy waste;

(iii) exploit local resources, intangible and cultural elements while taking into account their limits;

(iv) enhance the reproductive capacity and the conditions of the ecosystem renewal.

The diversity, cooperation, complementarities, and interdependence of the economics agents are sources of flexibility, renewal and adaptability of this industrial system.

Torre and Zimmermann emphasized the ecological dimension as the main specificities to the innovation framework [49]. The ecological dimension does not refer automatically to sustainable development, but rather to sustainability. In a generic way, it is the taking into account of living beings in their environment, their interactions, their adaptability, and their coevolution.

We, therefore, position our consideration on innovation ecosystems in an evolutionary sustainability perspective. These are our research questions: From an evolutionary perspective, what theoretical foundation(s) could justify the development of research on the innovation ecosystem concept face to traditional theoretical frameworks on innovation systems and clusters? What are the main implications for performance measures and sustainability conditions of innovation ecosystems? To answer these questions, we revisit the "Panarchy" model, which describes the evolutionary nature of complex adaptive systems and their sustainability [19].

\section{Methodological Framework}

In this paper, we follow in the footsteps of the innovation ecosystem as a complex adaptive system characterized by complex (formal, informal, organic, or institutional) relationships between heterogeneous actors, and by a mixed of top-down, bottom-up, and individual and collective initiatives that promote and foster the development of new products and services, as well as the co-evolution of heterogeneous players [20].

The adaptive cycle, Panarchy (Figure 1), describes the evolutionary process of complex adaptive systems and ecosystems [19]. This adaptive cycle includes four recursive phases, without, however, being deterministic. Namely, the reorganization phase, which will give rise to an exploitation phase, then the conservation phase and the decline phase, due to shocks or external variability. Adaptive mechanisms within the ecosystem will lead the ecosystem from a decline to a new reorganization phase.

These phases are different from phases describing the innovation ecosystem life cycle within the management field [28]. However, the Panarchy model offers an original perspective for the innovation ecosystem. Works on Panarchy rely on ecosystems sustainability, which is based on the ability to continuously adapt so as to reach their equilibrium state or several equilibrium states when faced with severe shocks and external variability [19].

The cycle is based on several important observations on natural ecosystems that echo the innovation ecosystems. In this paper, we highlight three of them:

1- An ecosystem lifecycle is characterized by one or more equilibrium states. This (or these) state(s) of equilibrium correspond(s) to the optimal situation when the functioning and outputs generation of this ecosystem are maximal.

2- An ecosystem lifecycle is interrupted by episodes of shocks and unpredictable disturbances with varying magnitudes that compromise these equilibrium states. These episodes of shock induce uncertainties for the ecosystem's future and constrain the ecosystem to activate adaptive mechanisms so as to launch the reorganization phase. The reorganization phase will be followed by the exploitation phase, which leads the ecosystem to regain its own, or another, equilibrium state. 
3- A duality determines an ecosystem's sustainability. On the one hand, the stabilization forces maintain productivity, the accumulation process, and the ecosystem efficiency. On the other hand, the destabilizing forces are essential to foster resilience and generativity.

In this study, we apply the adaptive cycle hypotheses on innovation ecosystem dynamics. We use the case of the dynamics of forests as natural ecosystems, as described in Gunderson and Holling's work [19]. It shows how these phases happen in practice when forests are submitted to forest fires. After highlighting the key elements, we test these phases on the characteristics of two emblematic cases of innovation ecosystems commonly studied in the literature: regional or local ecosystems and platform-based ecosystems (Figure 2).

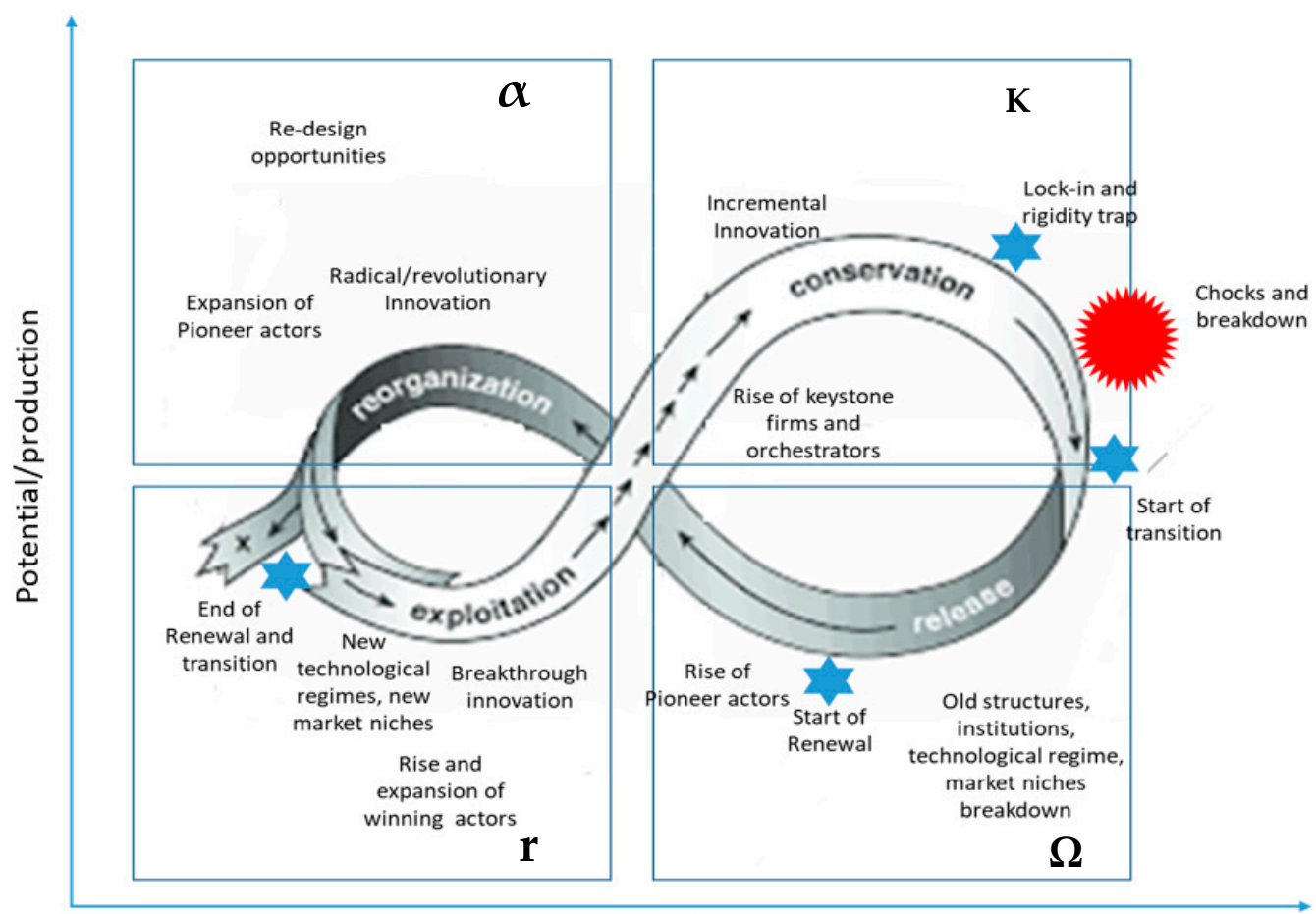

\section{Connectedness}

Figure 1. Panarchy applied to Innovation Ecosystem (adapted from Gunderson and Holling [19]).

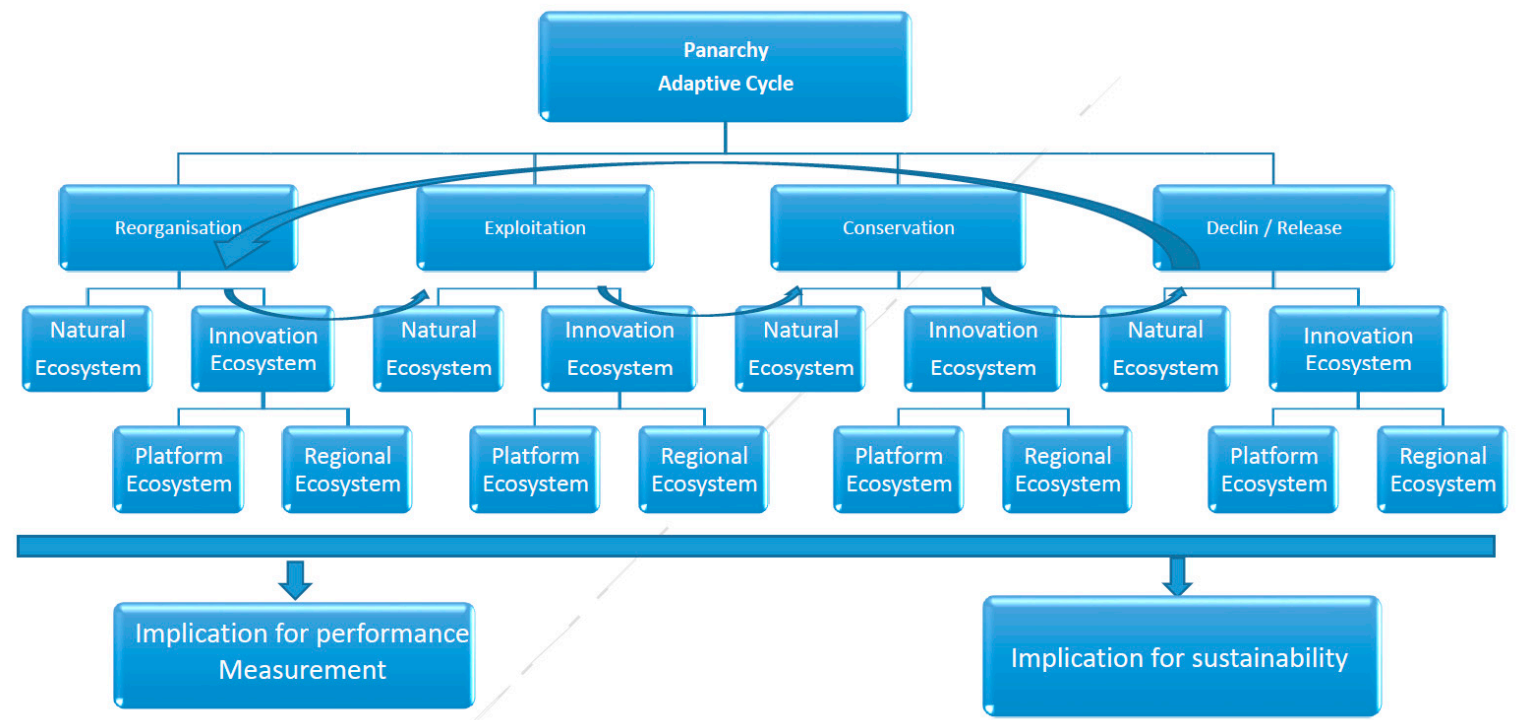

Figure 2. Method of the Panarchy model application to main cases of Innovation Ecosystems. 
Finally, we highlight the implications for innovation ecosystem performance measures and sustainability conditions.

\section{Applying the Panarchy Model to the Main Cases of Innovation Ecosystems}

In this paper, we start with the conservation phase because we believe it is more relevant to highlight adaptation mechanisms. We do not describe the creation process or the innovation ecosystem, a topic already much studied in the literature [28].

\subsection{Conservation Phase}

The so-called "conservation phase", noted as K (Figure 1) [19], corresponds to the optimal situation in the ecosystem dynamic in terms of performance, accumulation process, population size, as well as materials and energy flows. In this phase, the growth rate is initially very low and eventually becomes zero or declines. Connectivity between the different components is very high, which causes some rigidity in the ecosystem. At this stage, the ecosystem becomes more and more fragile and vulnerable to severe accidents and shocks because its resilience is weak.

In the case of a forest, trees reach maturity and the forest becomes very dense because of high connectivity and proximity between forest components. Production and energy flows are at the top. Nevertheless, this ecosystem is fragile. Dead leaves fall and some parts of trees and other plants become sclerotic. The conjunction of this situation and external factors such as rising temperatures during the summer period (drought leading to the evaporation of the water contained in plant tissues and to twigs and grass drying up) exposes this ecosystem to fire risks.

In the lifecycle of an innovation ecosystem, this phase relates to the maturity or leadership phase [28].

In the case of a regional innovation ecosystem, this phase is characterized by the maximum exploitation of a technological cycle, hyper-specialization, a high level of connectivity between actors, and an appropriate institutional environment. Those conditions foster the development and performance of this innovation ecosystem. The ecosystem then gets a competitive advantage over its competitors through cost or differentiation advantages. However, at the end of this phase, the technological waves that have supported the competitiveness of the innovation ecosystem are running out of steam. Even though incremental innovations are important, they can no longer generate permanent value creation for this innovation ecosystem. Relationships are becoming more and more formal and hierarchical. Firms and organizations might become bureaucratic and rigid or "locked into the patterns of traditional and vertically-integrated industrial structure" [41]. While the logic of specialization leads to exploiting a unique set of skills and technologies, they can, over time, cause a lock-in phenomenon. Institutions that fostered a business-friendly environment for exploiting the current technological waves might become inappropriate for generating a new technological paradigm. As a result, the innovation ecosystem may find itself in a hyperspecialization trap, institutional and structural rigidity, or lock-in. While this ecosystem resilience is low, a wave of creative destruction or market changes can, at any time, disrupt this ecosystem and lead it towards a phase of decline, as Schumpeter pointed out [50].

In the conservation phase, the platform-based ecosystem is in a leadership and competitive advantage position over competitors. Orchestration and complementarities between stakeholders are optimal. The platform has reached its critical mass, value creation, and growth [51]. The two main faces are very well structured, and the platform is running at full speed to design and manufacture new products and services. At the end of this phase, however, growth slows down. The influence of the leader or the keystone firm is weakening due to the wide range of actors whose interactions are increasingly complex. To optimize its influence, the keystone firm repositions its activity on its core business and develops more and more formal relationships and institutionalized interactions in order to safeguard its own growth. These strategies will have negative consequences for the growth of the whole platform ecosystem, thereby increasing its vulnerability (see Table 1) [52]. 
Table 1. Conservation phase.

\begin{tabular}{|c|c|c|c|c|}
\hline Ecosystems & Equilibrum Situation & $\begin{array}{c}\text { Main } \\
\text { Characteristics }\end{array}$ & Internal Vulnerabilities & $\begin{array}{l}\text { Indicators of } \\
\text { Efficiency }\end{array}$ \\
\hline $\begin{array}{c}\text { Forest } \\
\text { ecosystem }\end{array}$ & $\begin{array}{l}\text { Maximum accumulation } \\
\text { Maximum population } \\
\text { Optimal functioning of material } \\
\text { and energy flows }\end{array}$ & $\begin{array}{c}\text { Production }++++ \\
\text { Connectedness } \\
++++ \\
\text { Complementarities } \\
++++ \\
\text { Resilience }+\end{array}$ & $\begin{array}{c}\text { Tree maturity } \\
\text { Dead leaves tanks } \\
\text { Sclerosis of fragments of } \\
\text { trees and other plants }\end{array}$ & $\begin{array}{l}\text { Optimal functioning } \\
\text { of material and } \\
\text { energy flows }\end{array}$ \\
\hline $\begin{array}{l}\text { Regional } \\
\text { ecosystem }\end{array}$ & $\begin{array}{c}\text { Maximum exploitation of a } \\
\text { technological cycle } \\
\text { Adequate institutional } \\
\text { framework } \\
\text { Very strong connectivity } \\
\text { between actors with formal and } \\
\text { institutionalized relationships } \\
\text { Optimal allocation of resources } \\
\text { Hyper-specialization }\end{array}$ & \multirow{2}{*}{$\begin{array}{c}\text { Competitiveness } \\
++++ \\
\text { Connectedness } \\
++++ \\
\text { Complementarities } \\
++++ \\
\text { Resilience }+\end{array}$} & $\begin{array}{l}\text { Rigid, hierarchical } \\
\text { organization } \\
\text { Bureaucracy } \\
\text { Hyper-specialization } \\
\text { Path dependency }\end{array}$ & $\begin{array}{c}\text { Competitiveness } \\
\text { Attractiveness }\end{array}$ \\
\hline $\begin{array}{l}\text { Platform- } \\
\text { based } \\
\text { ecosystem }\end{array}$ & $\begin{array}{l}\text { Market leader position } \\
\text { Optimal layout around } \\
\text { Keystone firms and stakeholders } \\
\text { High complementarities } \\
\text { between actors } \\
\text { High attractiveness }\end{array}$ & & $\begin{array}{c}\text { Too many stakeholders } \\
\text { Decrease of Keystone firms } \\
\text { influence } \\
\text { Optimization and refocusing } \\
\text { on core activities and } \\
\text { profitable niches }\end{array}$ & $\begin{array}{l}\text { Value creation and } \\
\text { value-capture } \\
\text { Competitiveness } \\
\text { Attractiveness }\end{array}$ \\
\hline & - Weak & +++ High & ++++ Very High. & \\
\hline
\end{tabular}

\subsection{Decline Phase}

The decline phase is characterized by the situation where an external (or endogenous) event disturbs the initial equilibrium state of the ecosystem. It is noted as $\boldsymbol{\Omega}$ (Figure 1) [19].

In a forest ecosystem, the trigger event could be accidental: the occurrence of lightning, dry thunderstorms, or anthropic fires. [19]. This situation occurs when the conditions within this forest enable a small local fire to spread quickly enough to start a forest fire that can devastate hundreds or thousands of hectares (as was the case in Australia and the Amazon in 2019). Actually, strong destabilizing feedbacks occur between disturbing elements (lightning, dry storms, or small anthropic fire), established aggregates (mature forest trees, leaves, and dry grass), and other surrounding conditions (the oxygen in the air). The conjunction of these elements is sufficient to provide enough activation energy to torch the entire forest. This fire could hardly have spread if the forest had been very sparse. Forest vulnerability is due to population density and close proximity between the elements. The ecosystem then gets into a crisis situation where connections are broken and regulatory mechanisms weakened. This is the phase when the conditions for chaotic behavior are met.

This phase is related to the first step of the "renewal" phase for innovation ecosystems [28]. Consequently, the main disruptive elements are new technological and market changes, components of the creative destruction process.

In the case of a regional innovation ecosystem, this phase corresponds to the moment when industrial change and disruptive innovation disturb the technical status quo of existing technological and economic paradigms to generate new ones. This disruptive transformation process is inherent to the lifecycle of the regional innovation ecosystem and clusters. As a result, it destroys the value capture of well-established firms and organizations generated by a monopoly or oligopoly position associated with previous technological paradigms. This process submits the innovation ecosystem to uncertainties. This situation questions both orchestration and the position of dominants and periphery actors [53]. Control and regulation mechanisms are weakened, institutional and social boundaries dividing firms, as well as trust and confidence, break down. The survival of the ecosystem relies on adaptation mechanisms, new combinations, and organizational and institutional change [41]. Here are the most frequent indicators of these crises: delocalization of industrial activities and firms, sharp declines of foreign investment, loss of competitiveness. 
During the decline phase, the stakeholders of platform-based ecosystems experience a structural drop in their sales and in the capture of economic value. This situation may be due to the emergence of their market niches and core business of other platforms using better digital technologies or offering higher quality services at lower costs. It could also be explained by the value aspiration created by actors in very peripheral positions who are in connection with the core of a competing or complementary platform. This structural drop in profits can also result from the capture of value by a set of platforms on neighboring market niches. The platform-based ecosystem then risks disintegration. The actors and stakeholders who provided complementary services and products can leave the platform to create their own platforms or be plugged in other competing or complementary platforms [51]. A large proportion of users or customers have gone. The platform is in a hemorrhage and great-uncertainty situation. The adaptation of this ecosystem relies on the leader's and the remaining stakeholders' ability to find other development pathways. It depends on their capacity to appropriate new digital technologies that could make their offer more attractive. Adaptation could also mean to completely change their market niches or their initial core business. It is also the ability to stop the hemorrhage caused by the ongoing departure of users and stakeholders and to build confidence and a healthy environment. Even the leader's position could change.

To cope with these shocks and ensure their survival, a reorganization process must be initiated, whether in a platform-based ecosystem or a regional innovation ecosystem. This is the reorganization phase of the adaptive cycle (see Table 2).

Table 2. Decline phase

\begin{tabular}{|c|c|c|c|c|}
\hline Ecosystems & Decline Situation & $\begin{array}{c}\text { Main } \\
\text { Characteristics }\end{array}$ & Shock Activators & $\begin{array}{l}\text { Indicators of } \\
\text { Efficiency }\end{array}$ \\
\hline $\begin{array}{c}\text { Forest } \\
\text { ecosystem }\end{array}$ & Forest fire & $\begin{array}{c}\text { Production }+ \\
\text { Connectedness }+ \\
\text { Complementarities }+ \\
\text { Resilience }+++\end{array}$ & $\begin{array}{l}\text { Temperature rises } \\
\text { Drought } \\
\text { Fire from natural or } \\
\text { anthropic origin }\end{array}$ & $\begin{array}{c}\text { Resilience: } \\
\text { Resistance to chocks }\end{array}$ \\
\hline $\begin{array}{c}\text { Regional } \\
\text { ecosystem }\end{array}$ & $\begin{array}{c}\text { Technological disruption } \\
\text { Drop of competitiveness } \\
\text { Mass layoffs } \\
\text { Relocation of companies }\end{array}$ & \multirow{2}{*}{$\begin{array}{c}\text { Competitiveness }+ \\
\text { Connectedness }+ \\
\text { Complementarities }+ \\
\text { Resilience }+++\end{array}$} & $\begin{array}{l}\text { Creative destruction due to } \\
\text { the rise of new technological } \\
\text { waves } \\
\text { Evolution of the competitive } \\
\text { context }\end{array}$ & \multirow{2}{*}{$\begin{array}{c}\text { Resilience: } \\
\text { Resistance to drop of } \\
\text { competitiveness and } \\
\text { value creation }\end{array}$} \\
\hline $\begin{array}{l}\text { Platform- } \\
\text { based } \\
\text { ecosystem }\end{array}$ & $\begin{array}{l}\text { Technological disruption } \\
\text { Decline in value creation }\end{array}$ & & $\begin{array}{l}\text { Rise of competing platforms } \\
\text { Aspiration of value by } \\
\text { complementary platforms } \\
\text { Emergence of more efficient } \\
\text { digital technologies }\end{array}$ & \\
\hline & + Weak & $+++\mathrm{Hig}$ & ++++ Very High. & \\
\hline
\end{tabular}

\subsection{Reorganization Phase}

The reorganization phase, noted as $\alpha$ (Figure 1) [19], relates to the phase when the ecosystem turns to these residual resources and its regenerative capacity. This adaptive process relies on species that were not destroyed during the previous shock phase and can, therefore, survive within these new and harsh environmental conditions. This reorganization phase also relies on the emergence or expansion of so-called pioneer species or organisms that are beginning to take advantage of the uncertain environment.

As regards the forest ecosystem, the main adaptation actors are species coming from germinating seeds stored in seed banks accumulated from the past, as well as branches and tree trunks not consumed by the forest fire. The impact of the wind or birds or other animals can also bring them in [54]. They can come from the nutrients unconfined by organic matter decomposition or seed banks established in the soil. Diversity is essential for the reorganization process. Pioneer species might be varieties that were not widely represented or actively involved in previous conservation phases. They could 
even lay dormant and re-emerge after the decline phase to allow the ecosystem to adapt to future unforeseen external changes. As internal connectivity to the ecosystem is weak, pioneer species are very much influenced by external variability, both as opportunities to exploit and as constraints to bear. As a result, individuals and communities adapt to live in and exploit the opportunities of a variable environment with harsh and extreme conditions. They develop new combinations and relationships in order to reinforce each other. The future begins to be more predictable and less guided by uncertain forces independent from ecosystem control. This phase lays the foundations for the exploitation phase.

The reorganization phase is equivalent to the end of the renewal phase in an innovation ecosystem lifecycle. This phase is characterized mainly by the exploration, co-creation, regeneration, and restructuring of an innovation ecosystem. Works describing this phase are not many in the literature on innovation ecosystems.

In the case of a regional innovation ecosystem, this phase highlights the need for a creative class and diverse, pioneer actors within this ecosystem [55]. Individual or collective actions to explore and experiment novelties and new concepts become essential. The regulation processes and economic policies should be adapted to this transition and transformation period to achieve better change management. Disruptive innovations are developing from pre-existing technological niches [56]. Actors, companies, and organizations that will expand in this phase are mainly pioneer actors and risk-takers, who are able to deal with external variability (appropriating the new technological waves, adapting to the new competitive context) and the new conditions prevailing within the innovation ecosystem. This is a business-friendly environment for start-ups, spin-offs, and business angels development driven by a pioneering spirit. As a result, reorganizing the innovation ecosystem fosters the development of new products and services, new business models, new markets designed to create and capture economic value. Successful initiatives and success stories will recreate the confidence necessary for effective cooperation, collaboration, and the clustering process. The whole environment will gradually become more accommodating and more predictable. These pioneering behaviors foster new combinations and more complex relationships around new technologies or the exploitation of new markets. As the environment is more reliable, the exploitation phase can follow.

During the reorganization phase, a platform-based ecosystem is involved in a realignment and repositioning process in order to generate new innovative products or services and new complementary goods. The leader and stakeholders re-design or reinvent their value chain, attract new developer communities, and identify new business opportunities. This could happen through the appropriation of new digital technologies. Peripheral actors and users and developers' communities can make up a stock of new ideas or new concepts, which could allow reorganizing the platform. Routines are changing. Actors' positions in the ecosystem are also changing. Actors in the periphery position could move up at the heart of the platform or even become a leader. In this phase, former customers or users are reassured and find it worth staying. New stakeholders and new communities rejoin the former ones to create communities of interest, sharing a common vision. Coherence emerges, although not yet stabilized, the platform-based ecosystem is sufficient to enable stakeholders to move forward together in a new innovation process, a new trajectory, or the exploitation of a new business model.

This renewal process depends on the ability of this ecosystem to take into account changes in behaviors, to integrate new knowledge, to appropriate new technologies, or to adapt to new market conditions. A co-evolution process then begins, which will shape the final reconfiguration of the ecosystem (see Table 3).

\subsection{Exploitation Phase}

This phase, denoted as $\mathbf{r}$ (Figure 1) [19], relates to the phase when the growth-rate of the ecosystem is higher. The winning species are growing. The pioneer species may not necessarily become the winning species, but they create conditions for the exploitation phase by the winning species. New players emerge to strengthen the ecosystem. The environment is healthier, and the future becomes more predictable. Uncertain forces less guide the future of the ecosystem. Connectivity between species 
is intensifying. A complex relationship between cooperation and competition takes place, as well as self-organized relationships.

Table 3. Reorganization phase.

\begin{tabular}{|c|c|c|c|c|}
\hline Ecosystems & Situation & $\begin{array}{c}\text { Main } \\
\text { Characteristics } \\
\end{array}$ & $\begin{array}{c}\text { Internal and External } \\
\text { Elements of Re-Generativity }\end{array}$ & Indicators of Efficiency \\
\hline $\begin{array}{l}\text { Forest } \\
\text { ecosystem }\end{array}$ & $\begin{array}{c}\text { Mobilization of residual } \\
\text { resources } \\
\text { Development and } \\
\text { expansion of pioneer } \\
\text { species }\end{array}$ & $\begin{array}{c}\text { Production }++ \\
\text { New } \\
\text { Combinations }++++ \\
\text { New } \\
\text { Complementarities } \\
++++ \\
\text { Resilience }++++\end{array}$ & $\begin{array}{c}\text { Expansion of so-called pioneer } \\
\text { organisms or species } \\
\text { Ability of pioneer species to } \\
\text { live and exploit opportunities } \\
\text { in a harsh and extreme } \\
\text { environment } \\
\text { Arrivals of other exogenous } \\
\text { species }\end{array}$ & $\begin{array}{l}\text { Resilience: Regeneration } \\
\text { speed }\end{array}$ \\
\hline $\begin{array}{l}\text { Regional } \\
\text { ecosystem }\end{array}$ & $\begin{array}{c}\text { Reorganization, } \\
\text { restructuration } \\
\text { Mobilization of } \\
\text { technological niches } \\
\text { Exploitation of creative } \\
\text { class and underground } \\
\text { actors } \\
\text { Rise of pioneer actors }\end{array}$ & \multirow{2}{*}{$\begin{array}{c}\text { Competitiveness }++ \\
\text { New Combinations } \\
++++ \\
\text { New } \\
\text { Complementarities } \\
++++ \\
\text { Resilience++++ }\end{array}$} & $\begin{array}{c}\text { Incubation system } \\
\text { Creative class } \\
\text { Middleground artefact and } \\
\text { Underground actors } \\
\text { Exploration and } \\
\text { experimentation initiatives } \\
\text { Development of the start-up } \\
\text { spirit } \\
\text { Arrivals of exogenous actors } \\
\text { and risk-takers } \\
\text { New innovation policies }\end{array}$ & \multirow{2}{*}{$\begin{array}{c}\text { Resilience: } \\
\text { Speed in the } \\
\text { appropriation of } \\
\text { emerging technological } \\
\text { waves (digital), the } \\
\text { deployment of } \\
\text { technological niches, the } \\
\text { rearrangement of players } \\
\text { and the development of } \\
\text { new markets }\end{array}$} \\
\hline $\begin{array}{l}\text { Platform- } \\
\text { based } \\
\text { ecosystem }\end{array}$ & $\begin{array}{l}\text { Realignment and } \\
\text { repositioning of actors } \\
\text { Mobilization of } \\
\text { communities of users and } \\
\text { peripheral or external } \\
\text { developers communities }\end{array}$ & & $\begin{array}{c}\text { Re-design of new products } \\
\text { and services } \\
\text { Reinventing the value } \\
\text { proposition and the market } \\
\text { target } \\
\text { Attraction of new developer } \\
\text { communities } \\
\text { Reconfiguration of the } \\
\text { platform and repositioning of } \\
\text { stakeholders }\end{array}$ & \\
\hline & & & ry Hig & \\
\hline
\end{tabular}

In a forest ecosystem, at the exploitation phase, shrubs are in full development, and so is biodiversity. This ecosystem attracts exogenous species (e.g., insects, birds) that find favorable conditions to their development. Soils are improving, thanks to the decomposition of organic matter. Microclimatic variability is moderated by vegetation. Material and energy flows are becoming more and more secure. This results in a system of complex relationships, cooperation, mutualization, symbiosis, but also competition. As phase $\mathbf{r}$ progresses, the accumulation of nutrients and biomass becomes more and more closely linked to the existing vegetation, preventing other competitors from using them. Ecosystem connectivity increases with clustering processes.

In a regional innovation ecosystem, the exploitation phase relates to the phase generating increasing returns to scale, the exploitation of one or more new technological field(s), or new markets. The ecosystem is running at full speed. The institutional context fosters more and more innovations. Even a small incremental innovation leads to strong value creation. During this phase, the return on investment is very high. The development of complex relationships leads to a more efficient ecosystem by minimizing transaction costs and operations rationalization. Orchestrators emerge to improve the coherency of the ecosystem. Confidence is at its highest level, technical skills are developing, and markets are growing. This ecosystem is becoming very attractive for investors, talent, and entrepreneurs. Over time, competitive processes will create new monopoly and oligopoly situations, which harm the ecosystem diversity. Indeed, this situation will have consequences for newcomers and innovations: fewer opportunities to emerge, despite their potential superiority [57,58]. This is the start of the conservation phase. 
Regarding the platform-based ecosystem; at this phase, the platform is almost completely reformatted with the two main faces and the keystone firm. The core business and target market are very well-identified. On the innovation side, the first partners and developer groups are developing organic relationships and complementarities with the leader or new leaders. However, strategies to attract other developer communities are still operating. Old and new communities constitute a new community of destiny $[1,28]$. Identifying the core business provides immense opportunities for developing complementary and interdependent products and services. On the management or sales sides, the early loyal customers and the first new users will form the new market target. The evolution of preferences is captured by users' and consumers' data, which become the main factor of the innovation process. Now, it is all about attracting other customers and users. Harmonizing faces, once stabilized, becomes the main driver of the whole ecosystem. The platform can then develop expansion strategies and new value propositions through the development of a number of features. It can be a system of customer recommendations or rating, decentralized quality control, search engines, user-friendly access to the platform and a notification system that allows reaching other users who are connected to their customers on social networks [41].

The exploitation phase can lead to a new phase of maturity or conservation (see Table 4).

Table 4. Exploitation phase.

\begin{tabular}{|c|c|c|c|c|}
\hline Ecosystems & Situation & $\begin{array}{c}\text { Main } \\
\text { Characteristics }\end{array}$ & Exploitive Elements & $\begin{array}{l}\text { Indicators of } \\
\text { Efficiency }\end{array}$ \\
\hline $\begin{array}{c}\text { Forest } \\
\text { ecosystem }\end{array}$ & $\begin{array}{l}\text { Expansion of so-called } \\
\text { winning species } \\
\text { Development of networks } \\
\text { and complex cooperation } \\
\text { between species } \\
\text { Harmonization of energy } \\
\text { and material flows }\end{array}$ & $\begin{array}{c}\text { Production }+++ \\
\text { Connectedness }+++ \\
\text { Complementarities } \\
\quad+++ \\
\text { Resilience }++\end{array}$ & $\begin{array}{l}\text { Expansion of so-called winning } \\
\text { species } \\
\text { Development of complex } \\
\text { relationships, cooperation, } \\
\text { mutualization, and symbiosis } \\
\text { process }\end{array}$ & Growth rate \\
\hline $\begin{array}{l}\text { Regional } \\
\text { ecosystem }\end{array}$ & $\begin{array}{c}\text { Exploitation of new } \\
\text { technological waves and } \\
\text { new market conditions } \\
\text { Development of complex } \\
\text { networks and cooperation } \\
\text { Emergence of } \\
\text { orchestrating } \\
\text { actors/organization }\end{array}$ & \multirow{2}{*}{$\begin{array}{c}\text { Competitiveness }+++ \\
\text { Connectedness }+++ \\
\text { Complementarities } \\
+++ \\
\text { Resilience }++\end{array}$} & $\begin{array}{l}\text { Business incubation and } \\
\text { acceleration system } \\
\text { Innovation policies for } \\
\text { strengthening business } \\
\text { clusterization process and complex } \\
\text { relationships between actors } \\
\text { Development of unicorns and firms } \\
\text { with strong capacity to exploit new } \\
\text { technological paradigm }\end{array}$ & \multirow{2}{*}{$\begin{array}{c}\text { Growth rate } \\
\text { Increasing returns } \\
\text { of Innovation }\end{array}$} \\
\hline $\begin{array}{l}\text { Platform- } \\
\text { based } \\
\text { ecosystem }\end{array}$ & $\begin{array}{l}\text { Exploitation of new } \\
\text { business model, new } \\
\text { digital technologies, new } \\
\text { pools of customers or users } \\
\text { Harmonization of the } \\
\text { multi-faces of the platform } \\
\text { Strong feed-back between } \\
\text { Communities of } \\
\text { developers and } \\
\text { communities of users }\end{array}$ & & $\begin{array}{l}\text { Development of Common destiny } \\
\text { community between keystone firms, } \\
\text { stakeholders, peripheral developers, } \\
\text { users and consumers of the } \\
\text { renewed platform }\end{array}$ & \\
\hline
\end{tabular}

\section{Discussion}

The adaptive cycle, called Panarchy, provides an evolutionary and sustainability perspective, which is truly relevant to the innovation ecosystem concept and its main application. Operationally, this evolutionary vision already provides valuable tools for policy-makers and economic actors for better innovation policy implementation and innovation-related collective actions, or individual initiatives, as well.

First, this perspective shows that the dynamics of an innovation ecosystem relies on its adaptation capacity, which is mainly governed by two main dual functions. The first is the exploitation function, which maximizes value creation and value capture from a competitiveness perspective. The second is 
the generativity function, which maximizes creativity, invention, and exploration in a resilience and adaptation perspective.

The most obvious manifestation of the exploitation function could be seen during two phases of the Panarchy model: the exploitation phase and the conservation phase (maturity or leadership). These are characterized by cooperative and competitive strategies between a set of diverse actors in a business-friendly institutional context. They foster innovation processes or the exploitation of technological waves or market opportunities [20]. These phases prioritize growth and competitiveness due to the mastery of existing technological paradigms and market conditions. Here are the main performance indicators: growing returns from innovation, attractiveness, and value creation or value-capture [6]. This performance results from optimal allocation of resources, business-friendly institutions, complementarities, and complex relationships between actors, as well as maximum exploitation of one or more current technological cycles. The co-evolutionary trend depends, therefore, on a predictable context and a probable future.

Nevertheless, works on innovation ecosystems, as well as works on clusters and innovation systems, point out such favorable conditions that could foster innovation processes leading to competitiveness $[5,6,13,16,41,59-61]$. As a result, while fundamental, these ideas could not have a critical added value in the literature on the innovation process because they have already been studied and deepened by works on innovation systems and clusters. However, interactions between heterogeneous actors in a given institutional context meant to exploit technological waves and market conditions, even through the innovation process, could lead to the lock-in phenomenon [62].

This lock-in phenomenon may be the result of hyper-specialization, institutional and structural rigidity, and path-dependency [63,64]. In this situation, policies for clusters reinforcement and strategies for strengthening cooperation between actors are no longer sufficient to ensure sustainable performance. This ecosystem sustainability, therefore, depends on another force, which is part of its adaptive capacity: autopoiesis or generativity.

Here, we point out one of the main criticisms of the clusters works carried out by the advocates of the innovation ecosystem concept, which at the same time sheds light on the contribution of the ecosystem works resulting from ecological and sustainability perspective: the quasi-absence of cluster-specific mechanisms to avoid the lock-in phenomenon, as well as institutional and structural rigidity [65]. Without regeneration mechanisms, lock-in and institutional and structural rigidity could turn into a trap that prevents cluster renewal and could prove fatal to the cluster or the regional innovation system. This is what Saxenian observed in her study on the Route 128 regional innovation system [41]. Furthermore, while works on innovation systems dynamics do exist, their conceptual frameworks do not ontologically incorporate regenerative mechanisms. They are based essentially on institutionalist and interactionist points of view on innovation processes $[56,66]$.

Generativity or autopoiesis is the second major function that governs the adaptive capacity of innovation ecosystems as a social system [67]. It is particularly obvious during the decline and reorganization phases. These phases are characterized by a situation of great uncertainty and unforeseen crises. The objective of the innovation ecosystem is no longer to increase productivity gains or competitiveness. The ecosystem's performance is, therefore, its resilience. It relies on its speed in appropriating emerging technological waves and in adjusting actors' behaviors to market changes [19]. It also depends on the ability to build new value creation patterns. Reinforcing innovation ecosystem resilience requires creativity, invention, exploration, and exploiting diversity.

Cohendet et al. explain that this autopoiesis is essentially based on the underground, namely, talented elements, artists, peripheral actors, and informal communities [45]. Florida describes the crucial role of the creative class in exploring alternative pathways of value creation [55]. For platform-based ecosystems, generativity relies mainly on substantial feedbacks between keystone firms, main stakeholders, and communities of users or peripheral developers. Within the research system, this could arouse alternative research to the dominant paradigm. For the technological system, this could give rise to technological niches or communities of engineers working in their garages or third-places $[56,68]$. These peripheral 
or alternative elements are important for the resilience of the innovation ecosystem. In addition to diversity, the pioneering actors foster new combinations as well as experimenting and testing new pathways. Epistemic communities can be the bearers of collective action in this situation of weak ties and informal relationships [47]. Business incubators can facilitate individual high-risk initiatives by fostering start-up development. Nevertheless, firms' absorptive capacity also remains fundamental [69].

During the decline and reorganization phases, actors' coevolution becomes more complex due to the highly turbulent context, which even destabilizes established institutions. The reorganization of the ecosystem, a consequence of its generativity or autopoiesis, also relies on artefacts or "actants" that facilitate the circulation, testing, and exploitation of new ideas, new inventions ... [70,71]. These artefacts or "actants" also foster the appropriation of a new exogenous technological wave. They can prove to be places, platforms, spaces, and events that enable organic connections and interaction between research and industry, actors in the underground and those in the upperground, keystone firms, the main stakeholders of the platform, and users or peripheral developers communities $[45,47,72]$. These meetings are decisive for transitioning from ideas to concepts and from concepts to the success stories of pioneering initiatives that support the emergence of new innovation pathways.

These two major functions, exploitation and generativity or autopoiesis are obviously in tension, but determine both the resilience and competitiveness of the innovation ecosystem [73,74]. The performance of an innovation ecosystem is based on its ability to cope with these opposing or contradictory functions. It depends on the coexistence and best use, at an appropriate time, of the generative capacity and the exploitative capacity. It also depends on the capability of promoting tight and loose relationships between actors, collective (co-creation, co-design, co-development, and open innovation) and individual initiatives, openness logic (control of external variability) and use of its singularity, coherence and chaos initiatives, well-planned strategies, together with improvisation or spontaneity, as well as top-down and bottom-up initiatives. Furthermore, the performance of an innovation ecosystem relies on the coexistence of actors with different profiles: pioneers, consolidators, non-conformists, revolutionaries, leaders, and orchestrators [45].

While the coexistence of opposing forces is decisive for an innovation ecosystem performance and sustainability, the two functions cannot be maximized simultaneously. Actually, maximizing all of these forces together could damage the existence of this innovation ecosystem. These functions can only be maximized sequentially, as happens in natural ecosystems [19]. The optimization of a function depends on this ecosystem context and dynamics. In decline and reorganization phases, the obvious step is to optimize the generativity function. However, during the exploitation and conservation phases, the innovation ecosystem performance could result from the optimization of the exploitation function. Nevertheless, from a time perspective, the performance of an ecosystem depends on its ability to adapt quickly to an exogenous or endogenous shock and on remaining in an exploitation phase as long as possible. For an ecosystem, the risk is to lose one of these two pivots at the core of its ambidexterity [73]. Both functions determine the innovation ecosystem sustainability.

This analysis shows the advantage of revisiting the Panarchy model to consolidate the framework on innovation ecosystems and to highlight its relevance. The adaptive cycle developed within the framework of the "Panarchy" then becomes a relevant theoretical point if one is to understand-from an evolutionary and sustainability perspective-the ontological singularity of the framework of "innovation ecosystems" compared to more traditional theoretical frameworks on innovation systems and clusters.

\section{Conclusions}

While technological cycles get shorter in the digital era, volatile world economy, and globalization, adaptation issues are becoming increasingly critical. Today, economic agents find themselves at the crossroads of major challenges: the digital revolution (e.g., AI, blockchain, Industry 4.0), climate change, ecological and energy transitions, and the demographic transition. Furthermore, in a context of uncertainties and accelerating transformations, it becomes crucial to be able to build a path in 
uncertainty. Adaptation is, therefore, key for any firm and organization. It is obvious that, as a result, policy-makers and economic agents are looking for relevant frameworks or tools to enable them to be both competitive and resilient. Therefore, the innovation ecosystem framework proves to be relevant because it offers conceptual and operational tools, able to address both resilience and competitiveness through adaptation capacity. Adaptation implies the co-evolution of actors, institutions, networks, and knowledge. Revisiting the Panarchy model has enabled us to depict these fundamental properties and features of innovation ecosystems. The whole point of the innovation ecosystem framework is to provide economic actors and policy-makers who will avoid institutional and structural rigidity and technological lock-in. Moreover, the innovation ecosystem framework equips policymakers and practitioners to shorten decline situations caused by technological and market changes and to move toward reorganization and new exploitation phases. However, we do not assert that the four phases of the adaptive cycle are predetermined. An exploitative phase can even give rise to another exploitation phase. We only highlight properties and mechanisms, which foster the permanent adaptation of the innovation ecosystem to technological and market changes. We also point out which public policies and strategies are relevant according to the dynamics of an innovation ecosystem.

Future works on innovation ecosystems would be well advised to focus on dynamic, ecological, and evolutionary perspectives, which make it possible to model and capture the adaptation mechanisms of innovation ecosystems. Indeed, the innovation ecosystem framework and its contribution to the scientific literature on innovation processes cannot be fully understood without an evolutionary and sustainability perspective.

Funding: This research was funded by Hauts-de-France regional Concil. and "The APC was funded by Catholic Institute of Lille- HEMISF4IRE.

Conflicts of Interest: The authors declare no conflict of interest. The funders had no role in the design of the study; in the collection, analyses, or interpretation of data; in the writing of the manuscript, or in the decision to publish the results.

\section{References}

1. Moore, J.F. Predators and prey: A new ecology of competition. Harv. Bus. Rev. 1993, 71, 75-86. [PubMed]

2. Bogers, M.; Sims, J.; West, J. What is an ecosystem? Incorporating 25 years of ecosystem research. Presented at the 2019 Meeting of the Academy of Management, Boston, MA, USA, 9-13 August 2019; Available online: https://ssrn.com/abstract=3437014 (accessed on 14 January 2020).

3. Adner, R. Match your innovation strategy to your innovation ecosystem. Harv. Bus. Rev. 2006, 84, 98-107. [PubMed]

4. Kapoor, R. Ecosystems: Broadening the locus of value creation. J. Organ. Des. 2018, 7, 12. [CrossRef]

5. Tsujimoto, M.; Kajikawa, Y.; Tomita, J.; Matsumoto, Y. A review of the ecosystem concept-Towards coherent ecosystem design. Technol. Forecast. Soc. Chang. 2018, 136, 49-58. [CrossRef]

6. De Vasconcelos Gomes, L.A.; Facin, A.L.F.; Salerno, M.S.; Ikenami, R.K. Unpacking the innovation ecosystem construct: Evolution, gaps and trends. Technol. Forecast. Soc. Chang. 2018, 136, 30-48. [CrossRef]

7. Peltoniemi, M.; Vuori, E. Business ecosystem as the new approach to complex adaptive business environments. In Proceedings of the eBusiness Research Forum, Tampere, Finland, 20-24 September 2004; Volume 2, pp. 267-281.

8. Huang, J.; Wang, H.; Wu, J.; Yang, Z.; Hu, X.; Bao, M. Exploring the key driving forces of the sustainable intergenerational evolution of the industrial alliance innovation ecosystem: Evidence from a case study of China's TDIA. Sustainability 2020, 12, 1320. [CrossRef]

9. Ritala, P.; Almpanopoulou, A. In defense of 'eco'in innovation ecosystem. Technovation 2017, 60, 39-42. [CrossRef]

10. Frosch, R.A.; Gallopoulos, N.E. Strategies for manufacturing. Sci. Am. 1989, 261, 144-152. [CrossRef]

11. Marshall, A. Principles of Economics, 8th ed.; Cengage Learning: London, UK, 2009.

12. Becattini, G.; Bellandi, M.; De Propris, L. A Handbook of Industrial Districts; Edward Elgar Publishing: Cheltenham, UK, 2014. 
13. Porter, M.E. Clusters and the New Economics of Competition; Harvard Business School Press: Boston, MA, USA, 1998; Volume 76, pp. 77-90.

14. Freeman, C. Technology Policy and Economic Performance; Pinter Publishers: London, UK, 1989; p. 34.

15. Lundvall, B.Å. National Systems of Innovation: Toward a Theory of Innovation and Interactive Learning; Anthem press: London, UK, 2010; Volume 2.

16. Malerba, F. Sectoral systems of innovation and production. Res. Policy 2002, 31, 247-264. [CrossRef]

17. Cooke, P. Regional innovation systems: Competitive regulation in the new Europe. Geoforum 1992, 23, 365-382. [CrossRef]

18. Oh, D.S.; Phillips, F.; Park, S.; Lee, E. Innovation ecosystems: A critical examination. Technovation 2016, 54, 1-6. [CrossRef]

19. Gunderson, L.H.; Holling, C.S. Panarchy: Understanding Transformations in Human and Natural Systems; Island press: Washington, DC, USA, 2001.

20. Russell, M.G.; Smorodinskaya, N.V. Leveraging complexity for ecosystemic innovation. Technol. Forecast. Soc. Chang. 2018, 136, 114-131. [CrossRef]

21. Chesbrough, H.W.; Vanhaverbeke, W.; West, J. Open Innovation: Researching a New Paradigm; Oxford University Press: Oxford, UK, 2006.

22. Chesbrough, H.W.; Kim, S.; Agogino, A. Building an open innovation ecosystem. Calif. Manag. Rev. 2014, 56, 144-171. [CrossRef]

23. Rohrbeck, R.; Hölzle, K.; Gemünden, H.G. Opening up for competitive advantage-How Deutsche Telekom creates an open innovation ecosystem. RED Manag. 2009, 39, 420-430.

24. Krishnamurthy, S.; Tripathi, A.K. Monetary donations to an open source software platform. Res. Policy 2009, 38, 404-414. [CrossRef]

25. Barney, J.B.; Hesterly, W.S. Strategic Management and Competitive Advantage: Concepts and Cases, 5th ed.; Prentice Hall: Upper Saddle River, NJ, USA, 2010.

26. Porter, M.E. Competitive Advantage: Creating and Sustaining Superior Performance; Free Press: New York, NY, USA, 1985.

27. Teece, D.J. Profiting from technological innovation: Implications for integration, collaboration, licensing and public policy. Res. Policy 1986, 15, 285-305. [CrossRef]

28. Moore, J.F. The Death of Competition: Leadership and Strategy in the Age of Business Ecosystems; Harper Business: New York, NY, USA, 1996.

29. Teece, D.J. Explicating dynamic capabilities: The nature and microfoundations of (sustainable) enterprise performance. Strateg. Manag. J. 2007, 28, 1319-1350. [CrossRef]

30. Jones, G.R. Organizational Theory, Design, and Change; Pearson: Upper Saddle River, NJ, USA, 2013.

31. Powell, W.W.; Koput, K.W.; Smith-Doerr, L. Interorganizational collaboration and the locus of innovation: Networks of learning in biotechnology. Adm. Sci. Q. 1996, 41, 116-145. [CrossRef]

32. Santos, F.M.; Eisenhardt, K.M. Organizational boundaries and theories of organization. Organ. Sci. 2005, 16, 491-508. [CrossRef]

33. Nelson, R.; Winter, S.G. An Evolutionary Theory of Economic Change; Belknap Press/Harvard University Press: Cambridge, MA, USA, 1982.

34. Ayres, R.U.; Ayres, L. A Handbook of Industrial Ecology; Edward Elgar Publishing: Cheltenham, UK, 2002.

35. Tiwana, A. Platform Ecosystems: Aligning Architecture, Governance, and Strategy; Murgan Kaufman Publishers: Burlington, MA USA, 2013.

36. Isckia, T. Amazon's evolving ecosystem: A cyber-bookstore and application service provider. Can. J. Adm. Sci. 2009, 26, 332-343. [CrossRef]

37. Gawer, A.; Cusumano, M.A. Industry platforms and ecosystem innovation. J. Prod. Innov. Manag. 2014, 31, 417-433. [CrossRef]

38. Iansiti, M.; Levien, R. The Keystone Advantage: What the New Dynamics of Business Ecosystems Mean for Strategy, Innovation, and Sustainability; Harvard Business Press: Brighton, MA, USA, 2004.

39. Gawer, A.; Cusumano, M.A. How companies become platform leaders. MIT Sloan Manag. 2008, 49, 68-75.

40. Isckia, T. Ecosystèmes d'affaires, stratégies de plateforme et innovation ouverte: Vers une approche intégrée de la dynamique d'innovation. Manag. Avenir 2011, 6, 157-176. [CrossRef]

41. Saxenian, A. Regional Networks: Industrial Adaptation in Silicon Valley and Route 128; Harvard University Press: Cambridge, MA, USA, 1994. 
42. Radziwon, A.; Bogers, M.; Bilberg, A. Creating and capturing value in a regional innovation ecosystem: A study of how manufacturing SMEs develop collaborative solutions. Int. J. Technol. Manag. 2017, 75, 1-4.

43. Viitanen, J. Profiling regional innovation ecosystems as functional collaborative systems: The case of Cambridge. Technol. Innov. Manag. Rev. 2016, 6, 12. [CrossRef]

44. Grandadam, D.; Cohendet, P.; Simon, L. Places, spaces and the dynamics of creativity: The video game industry in Montreal. Reg. Stud. 2013, 47, 1701-1714. [CrossRef]

45. Cohendet, P.; Grandadam, D.; Simon, L. The anatomy of the creative city. Ind. Innov. 2010, 17, 91-111. [CrossRef]

46. Lange, B.; Schüßler, E. Unpacking the middleground of creative cities: Spatiotemporal dynamics in the configuration of the Berlin design field. Reg. Stud. 2018, 52, 1548-1558. [CrossRef]

47. Sarazin, B.; Simon, L.; Cohendet, P. Les communautés D'innovation: De la Liberté Créatrice à L'innovation Organisée; Éditions EMS: Caen, France, 2017.

48. Korhonen, J. Four ecosystem principles for an industrial ecosystem. J. Clean. Prod. 2001, 9, 253-259. [CrossRef]

49. Torre, A.; Zimmermann, J.B. Des clusters aux écosystèmes industriels locaux. Rev. D'économie Ind. 2015, 4, 13-38. [CrossRef]

50. Schumpeter, J. Capitalism, Socialism and Democracy; Routledge: Abingdon-on-Thames, UK, 1942.

51. Isckia, T.; De Reuver, M.; Lescop, D. Toward an Evolutionary Framework for Platform-Based Ecosystem Analysis. 2018. Available online: https://hal.archives-ouvertes.fr/hal-01992440 (accessed on 14 January 2020).

52. Fautrero, V.; Gueguen, G. Quand la domination du leader contribue au déclin. Rev. Fr. Gest. 2012, 3, $107-121$. [CrossRef]

53. Pinkse, J.; Vernay, A.L.; D'Ippolito, B. An organisational perspective on the cluster paradox: Exploring how members of a cluster manage the tension between continuity and renewal. Res. Policy 2018, 47, 674-685. [CrossRef]

54. Franklin, J.F.; Spies, T.A.; Van Pelt, R.; Carey, A.B.; Thornburgh, D.A.; Berg, D.R.; Bible, K. Disturbances and structural development of natural forest ecosystems with silvicultural implications, using Douglas-fir forests as an example. Forest Ecol. Manag. 2002, 155, 399-423. [CrossRef]

55. Florida, R. Cities and the Creative Class; Routledge: Abingdon-on-Thames, UK, 2005.

56. Elzen, B.; Geels, F.W.; Green, K. System Innovation And the Transition to Sustainability: Theory, Evidence and Policy; Edward Elgar Publishing: Cheltenham, UK, 2004.

57. Bode, S.; Hübl, L.; Schaffner, J.; Twelemann, S. Discrimination Against Newcomers: Impacts of the German Emission Trading Regime on the Electricity Sector. Diskussionsbeitrag, Leibniz Universität Hannover, Hannover, Germany, 2005.

58. Lau, A.K.; Lo, W. Regional innovation system, absorptive capacity and innovation performance: An empirical study. Technol. Forecast. Soc. Chang. 2015, 92, 99-114. [CrossRef]

59. Porter, M.E. Competitive advantage, agglomeration economies, and regional policy. Int. Reg. Sci. Rev. 1996, 19, 85-90. [CrossRef]

60. Porter, M.E. Locations, clusters, and company strategy. In The Oxford Handbook of Economic Geography; Clark, G.L., Gertler, M.S., Feldman, M.P., Williams, K., Eds.; Oxford University Press: Oxford, UK; New York, NY, USA; pp. 253, 274.

61. Edquist, C. Systems of Innovation: Technologies, Institutions and Organizations; Routledge: Abingdon-on-Thames, UK, 2013.

62. Barnes, W.; Gartland, M.; Stack, M. Old habits die hard: Path dependency and behavioral lock-in. J. Econ. Issues 2004, 38, 371-377. [CrossRef]

63. Liebowitz, S.; Margolis, S.E. Path Dependence and Lock-In; Edward Elgar Publishing: Cheltenham, UK, 2014.

64. Puffert, D.J. Path Dependence, Network Form and Technological Change; Stanford University Press: Stanford, CA, USA, 2000.

65. Zucchella, A. Local cluster dynamics: Trajectories of mature industrial districts between decline and multiple embeddedness. J. Inst. Econ. 2006, 2, 21-44. [CrossRef]

66. Amable, B. Les systèmes d'innovation. In Encyclopédie de L'innovation; Mustar, P., Penan, H., Eds.; Economica: Paris, France, 2003; pp. 367-382.

67. Luhmann, N. The autopoiesis of social systems. In Sociocybernetic Paradoxes: Observation, Control and Evolution of Self-Steering Systems; Geyer, F., Van d. Zeuwen, J., Eds.; Sage: London, UK, 1986; pp. 172-192.

68. Oldenburg, R. The Great Good Place: Café, Coffee Shops, Community Centers, Beauty Parlors, General Stores, Bars, Hangouts, and How They Get You Through the Day; Da Capo Press: Cambridge, MA, USA, 1989. 
69. Cohen, W.M.; Levinthal, D.A. Absorptive capacity: A new perspective on learning and innovation. Adm. Sci. Q. 1990, 35, 128-152. [CrossRef]

70. Pigford, A.A.E.; Hickey, G.M.; Klerkx, L. Beyond agricultural innovation systems? Exploring an agricultural innovation ecosystems approach for niche design and development in sustainability transitions. Agric. Syst. 2018, 164, 116-121. [CrossRef]

71. Granstrand, O.; Holgersson, M. Innovation ecosystems: A conceptual review and a new definition. Technovation 2019, 90-91, 102098. [CrossRef]

72. Xu, G.; Wu, Y.; Minshall, T.; Zhou, Y. Exploring innovation ecosystems across science, technology, and business: A case of 3D printing in China. Technol. Forecast. Soc. Chang. 2018, 136, 208-221. [CrossRef]

73. Andriopoulos, C.; Lewis, M.W. Exploitation-exploration tensions and organizational ambidexterity: Managing paradoxes of innovation. Organ. Sci. 2009, 20, 696-717. [CrossRef]

74. Eaton, B.; Elaluf-Calderwood, S.; Sørensen, C.; Yoo, Y. Dynamic structures of control and generativity in digital ecosystem service innovation: The cases of the Apple and Google mobile app stores. Lond. Sch. Econ. Polit. Sci. 2011, 44, 1-25.

(C) 2020 by the author. Licensee MDPI, Basel, Switzerland. This article is an open access article distributed under the terms and conditions of the Creative Commons Attribution (CC BY) license (http://creativecommons.org/licenses/by/4.0/). 